\begin{tabular}{l|l} 
Jurnal Eksplorasi Akuntansi & $\begin{array}{l}\text { ISSN : 2656-3649 (Online) } \\
\text { Vol. 1, No 4, Seri A, November 2019, Hal 1650-1665://jea.ppj.unp.ac.id/index.php/jea/issue/view/14 }\end{array}$
\end{tabular}

\title{
PENGARUH COGNITIVE DISSONANCE BIAS, OVERCONFIDENCE BIAS DAN HERDING BIAS TERHADAP PENGAMBILAN KEPUTUSAN INVESTASI
}

\section{(Studi Empiris Pada Mahasiswa Fakultas Ekonomi Universitas Negeri Padang Yang Melakukan Investasi Di Bursa Efek Indonesia)}

\author{
Dila Afriani ${ }^{1}$, Halmawati ${ }^{2}$ \\ ${ }^{1}$ Alumni Jurusan Akuntansi Fakultas Ekonomi, Universitas Negeri Padang \\ ${ }^{2}$ Jurusan Akuntansi Fakultas Ekonomi, Universitas Negeri Padang \\ *Korespondensi: dilaafriani02@gmail.com
}

\begin{abstract}
This study aims to determine whether cognitive dissonance bias, overconfidence bias and herding bias have a significant effect on stock investment decision making partially and simultaneously. the sample in this study were students of the Faculty of Economics, Padang State University. The sampling technique was simple random sampling. A total of 133 questionnaires were returned in complete condition and processed. by using multiple linear regression techniques, the results show that cognitive dissonance bias and overconfidence bias do not affect stock investment decisions. Herding bias has a positive and significant influence on stock investment decision making.
\end{abstract}

Keywords: Cognitive dissonance bias; overconfidence bias; herding bias; investment decision making.

How to cite (APA $6^{\text {th }}$ style)

Afriani, Dila. \& Halmawati. (2019). Pengaruh Cognitive Dissonance Bias, Overconfidence Bias dan Herding Bias Terhadap Pengambilan Keputusan Investasi (Studi Empiris pada Mahasiswa Fakultas Ekonomi Universitas Negeri Padang yang Melakukan Investasi di Bursa Efek Indonesia). Jurnal Eksplorasi Akuntansi, 1(4), Seri A, 1650-1665.

\section{PENDAHULUAN}

Pasar modal di Indonesia bukan sebagai penggerak utama dalam roda perekonomian negara, walau demikian peran pasar modal tetap dipandang cukup penting sebagai salah satu barometer kondisi perekonomian suatu negara serta sebagai alternatif bagi pendanaan dan sarana berinvestasi. Pasar modal Indonesia saat ini sedang dalam proses pembentukan menuju pendewasaan pelaku pasar, ada kecenderungan bahwa para investor mempertimbangkan informasi akuntansi sebelum membuat keputusan investasi (Puspaningtyas, 2010).

Informasi akuntansi bagi perusahaan yang terdaftar di pasar modal mempunyai peranan sangat penting dalam membentuk pasar modal yang efisien. Informasi akuntansi dalam arti bentuk dan isinya mempunyai pengaruh yang kuat terhadap pengambilan keputusan investasi para investor (Wignjohartojo, 1995; Harianto dan Sudomo, 2001; Hamzah, 2005; Hartono, 2008 dalam Puspaningtyas, 2010; Aisyah at all, 2019). 
Investasi adalah salah satu bentuk penanaman modal seseorang di masa sekarang dengan harapan mendapatkan imbalan di masa yang akan datang. Tandelilin (2010) menjelaskan beberapa alasan seseorang melakukan investasi seperti untuk kehidupan yang lebih layak di masa depan, mengurangi tekanan inflasi, dan dorongan untuk menghemat pajak. Investasi pada hakikatnya merupakan suatu pengorbanan yang dilakukan oleh investor di masa sekarang untuk mendapatkan keuntungan di masa yang akan datang dengan mempertimbangkan risiko yang akan dihadapi

Setiap informasi mengenai suatu perusahaan menyebabkan perubahan dalam keyakinan, persepsi dan penilaian investor terhadap nilai perusahaan (Puspitaningtyas, 2007). Informasi akuntansi yang terkandung dalam laporan keuangan harus memberikan nilai manfaat (useful) kepada para penggunanya (users) dalam hal pengambilan keputusan. Konsep relevansi nilai informasi akuntansi menjelaskan tentang bagaimana investor bereaksi terhadap pengumuman informasi akuntansi, reaksi ini akan membuktikan bahwa kandungan informasi akuntansi merupakan isu yang sangat penting dalam proses pengambilan keputusan investasi, sehingga dapat dikatakan bahwa informasi akuntansi bermanfaat (useful) bagi investor (Aprillianto, Wulandari dan Kurrohman , 2014).

Selain membuat analisis fundamental investor di pasar saham harus peka dan pandai membaca tren yang ada, investor harus melacak dan memahami siklus fluktuasi harga saham. Informasi akuntansi sebagai salah satu basis informasi dalam pengambilan keputusan investasi merupakan kandungan internal yang dapat diperoleh dari laporan keuangan perusahaan melalui teknik analisis fundamental. Analisis fundamental atau analisis laporan keuangan (financial statements analysis) bertujuan untuk menyediakan data yang berhubungan dengan perusahaan yang diperlukan dalam proses pengambilan keputusan investasi. Keputusan investasi yang dimaksud adalah keputusan untuk membeli, menjual, atau pun mempertahankan kepemilikan saham (Puspaningtyas, 2010). Adanya informasi yang lengkap, akurat serta tepat waktu memungkinkan investor untuk melakukan pengambilan keputusan secara rasional sehingga hasil yang diperoleh sesuai dengan yang diharapkan (Sembiring, 2005 dalam Puspitaningtyas, 2007).

Keberhasilan investasi seorang investor pada dasarnya ditentukan oleh seberapa tepat keputusan yang diambil dan mampu menentukan dengan tepat dan baik jenis maupun waktu investasi yang memiliki probabilitas yang lebih besar untuk mendapatkan keuntungan (return). Keputusan investasi yang diambil seorang investor akan berbeda dengan investor lainnya disebabkan adanya faktor psikologi yang berbeda yang mempengaruhi masing-masing investor dalam mengambil keputusan investasi (Seto, 2017). Pertimbangan atas kemungkinan yang akan terjadi tersebut mempengaruhi seorang investor bertindak rasional ataupun irasional dalam mengambil keputusan. Pendekatan decision usefulness mengasumsikan bahwa investor adalah individu yang rasional. Artinya, individu yang mempertimbangkan trade-off antara tingkat return yang diharapkan dengan tingkat risiko yang akan dihadapi dalam keputusan investasinya, dan memilih tindakan yang akan menghasilkan expected utility yang paling tinggi (Puspanityas, 2010).

Investor yang rasional adalah investor yang selalu menanggapi informasi baru yang didapat dan membuat pilihan-pilihan yang secara normatif dapat diterima (Subash, 2012). Sikap irasional sangat dipengaruhi oleh faktor psikologi dalam diri investor. Keterlibatan emosi, kesukaan, sifat dan berbagai macam hal yang melekat di dalam diri manusia dapat menyebabkan manusia bertindak irasional dalam mengambil keputusan (Budiarto dan Susanti, 2017). Dampak dari irasionalitas seorang investor dalam pasar modal menyebabkan tidak maksimalnya keuntungan maupun hilangnya kesempatan untuk memperoleh pengembalian yang diharapkan 
dari investasi serta menyebabkan pasar menjadi panik dan berpotensi mengacaukan pasar, sehingga pasar bergerak menjadi tidak normal dan efisien.

Kenyataan menunjukkan bahwa proses pengambilan keputusan individu ternyata jauh lebih kompleks dari yang diasumsikan teori utilitas harapan, terdapat kesenjangan yang besar antara konsep rasionalitas yang diasumsikan ilmu ekonomi dengan konsep rasionalitas yang digunakan manusia dalam mengambil keputusan di dunia nyata (Suartana, 2010). Teori prospek yang dikemukan oleh Kahneman dan Tversky (1979) menjelaskan berbagai keadaan pemikiran yang dapat mempengaruhi proses pengambilan keputusan investor, teori ini menggabungkan 2 (dua) ilmu yang berbeda yaitu ekonomi dan psikologi. Teori ini beranggapan bahwa perilaku manusia dianggap aneh dan kontradiktif dalam mengambil keputusan dan tidak selamanya rasional.

Shefrin (2007) dalam Setiawan, Atahau, dan Robiyanto (2018) menjelaskan bahwa bias perilaku merupakan kecenderungan kesalahan prediksi. Bias perilaku terdiri dari faktor kognitif dan emosi dari dalam diri masing- masing individu yang dapat mempengaruhinya dalam pengambilan keputusan investasi. Pompian (2006) dalam Pradhana (2018) menjelaskan bahwa bias dibagi menjadi dua kategori yaitu cognitive bias dan emotinal bias. Bias kognitif (cognitive bias) adalah penyimpangan dalam proses pemahamam, pengolahan, dan pengambilan keputusan atas suatu informasi atau fakta. Sedangkan bias emosional (emotional bias) adalah penyimpangan karena menitikberatkan pada perasaan dan spontanitas dari pada fakta.

Penelitian yang dilakukan Umairoh (2012) pada investor di Salatiga terkait dengan cognitive bias dan emotional bias dalam pengambilan keputusan investasi mendapatkan hasil bahwa cognitive dissonance bias tidak berpengaruh signifikan. Cognitive dissonance bias adalah keadaan ketidakseimbangan yang terjadi ketika kognitif itu sendiri tidak sesuai dimana terjadi suatu konflik yang muncul dari informasi yang baru diperoleh berbeda dengan pemahaman yang sudah diterima sebelumnya (Umairoh, 2012). Pradhana (2018) meneliti pengaruh financial literacy, cognitive bias dan emotional bias terhadap keputusan investasi di surabaya, menyatakan bahwa cognitive dissonance tidak berpengaruh terhadap keputusan investasi. Secara tidak langsung penelitian tersebut mendukung penelitian Umairoh (2012).

Kondisi emosi dari psikologi investor juga dapat mempengaruhi pengambilan keputusan. Overconfidence adalah suatu kondisi dimana seorang investor cenderung terlalu yakin terhadap kemampuan dan pengetahuannya dalam mengambil keputusan. Jannah dan Ady (2017) melakukan penelitian mengenai analisis fundamental, suku bunga, dan overconfidence terhadap pengambilan keputusan investasi pada investor di Surabaya. Hasil menunjukkan bahwa perilaku overconfidence berpengaruh dalam pengambilan keputusan investasi. Penelitian yang dilakukan Paramita, Isbanah dan Purwohandoko (2018) menyatakan bahwa overconfidence tidak mempengaruhi perilaku investor. Overconfidence menyebabkan orang melebih-lebihkan pengetahuan, meremehkan risiko dan melebih-lebihkan kemampuan dalam hal kontrol atas apa yang terjadi. Beberapa penelitian tersebut menunjukkan hasil yang berbeda terkait dengan perilaku overconfidence dalam mengambil keputusan investasi di pasar saham.

Pengambilan keputusan investasi sendiri tidak hanya dipengaruhi oleh faktor kognitif dan emosional saja melainkan ada faktor sosial yang mempengaruhinya. Penelitian Fityani (2015) adanya variabel sosial yang mempengaruhi seorang investor dalam mengambil keputusan yaitu herding. Herding merupakan perilaku investor yang cenderung mengikuti keputusan investor lain dalam berinvestasi. Hasil dari penelitian Ramdhani (2018) menunjukan bahwa herding behavior berpengaruh positif atau signifikan terhadap pengambilan keputusan investasi oleh investor muda yang ada di Yogyakarta. Danepo (2018) dalam penelitiannya tentang pengaruh 
bias perilaku investor terhadap keputusan investasi di pasar saham. Hasil penelitiannya menunjukkan perilaku herding berpengaruh positif dan signifikan terhadap keputusan investasi. Hasil ini dapat dimaknai bahwa semakin besar perilaku herding yang dimiliki investor maka akan mempengaruhi keputusan investasinya. Penelitian ini bertujuan untuk memberikan bukti empiris mengenai pengaruh cognitive dissonance bias, overconfidence bias dan herding bias terhadap pengambilan keputusan investasi saham, pada mahasiswa Fakultas Ekonomi Universitas Negeri Padang yang melakukan investasi di Bursa Efek Indonesia.

\section{REVIU LITERATUR DAN HIPOTESIS PENELITIAN Behavioral Finance}

Behavioral finance yaitu suatu ilmu yang menjelaskan bagaimana faktor kognitif dan emosi mampu mempengaruhi pengambilan keputusan keuangan. Behavioral finance menjelaskan dan meningkatkan pemahaman tentang pola penalaran investor, serta pola emosional yang terlibat dan sejauh mana mempengaruhi pengambilan keputusan investasi (Ricciardi dan Simon, 2000). Bodie, Kane dan Marcus (2016) menjelaskan behavioral finance merupakan sebuah model pasar keuangan yang menekankan potensi implikasi faktor psikologis yang mempengaruhi perilaku investor. Ketidakrasionalan ini terbagi menjadi dua kategori. Pertama, bahwa investor tidak selalu memproses informasi dengan benar dan karenanya menyimpulkan distribusi probabilitas yang salah tentang tingkat pengembalian di masa depan. Kedua, bahkan diberi distribusi probabilitas pengembalian, investor sering membuat keputusan yang tidak konsisten atau sistematis secara optimal.

\section{Prospect Theory}

Teori prospek yang dikemukan oleh Kahneman dan Tversky (1979) merupakan teori yang menjelaskan bagaimana pengambilan keputusan yang dilakukan oleh manusia yang hasilnya belum pasti dalam suatu keadaan. Teori prospek menegaskan bahwa seseorang tidak selalu bertindak rasional dibawah risiko dan ketidakpastian, seseorang akan dipengaruhi oleh faktor psikologi dan perilaku yang tidak menentu dalam mengambil keputusan yang rasional (Pradikasari dan Isbanah, 2018). Pengambilan keputusan pembelian yang dilakukan oleh investor tidak hanya berdasarkan pertimbangan rasional semata. Aspek emosional turut berpengaruh dalam pengambilan keputusan investasi. Ricciardi dan Simon (2000) menjelaskan teori prospek berhubungan dengan gagasan bahwa individu tidak selalu berperilaku rasional. Teori ini menyatakan bahwa ada bias yang terus menerus dimotivasi oleh faktor-faktor psikologis mempengaruhi pilihan individu dalam kondisi ketidakpastian.

\section{Keputusan Investasi}

Subash (2012) menyatakan keputusan investasi dapat didefinisikan sebagai proses pemilihan alternatif tertentu dari berbagai alternatif yang ada. Mengambil keputusan investasi merupakan salah satu tantangan penting yang dihadapi oleh investor. Ini merupakan suatu proses yang rumit yang melibatkan analisis berbagai faktor personal, teknis dan situasional. Pemahaman aspek psikologi merupakan hal yang penting dalam proses pengambilan keputusan investasi yang efektif.

\section{Cognitive Dissonance Bias}

Cognitive dissonance adalah keadaan ketidakseimbangan yang terjadi ketika kognitif itu sendiri tidak sesuai. Suatu keadaan atau situasi ketika konflik muncul dari informasi baru yang diperoleh 
berbeda dengan pemahaman yang sudah diterima sebelumnya (Umairoh, 2012). Disonansi kognitif merupakan suatu situasi dimana orang tidak nyaman dengan informasi baru yang didapatkannya yang menimbulkan keraguan dari pemahaman awal yang diterima sebelumnya (Pompian, 2006 dalam Jannah dan Ady, 2017).

\section{Overconfidence Bias}

Overconfidence merupakan kecenderungan untuk terlalu yakin atas kemampuan dan prediksi untuk berhasil. Kondisi ini merupakan hal normal yang sekaligus merupakan cerminan dari tingkat keyakinan seseorang untuk mencapai atau mendapatkan sesuatu. Tidak bisa disangkal bahwa manusia memiliki kepercayaan diri yang tinggi termasuk dalam berinvestasi (Gozalie dan Anastasia, 2015). Konsekuensi dari overconfidence adalah investor yang akan overestimate terhadap kemampuannya untuk mengevaluasi perusahaan sebagai investasi yang potensial, cenderung untuk melakukan perdagangan yang berlebihan (overtrading), dan underestimate terhadap risiko.

\section{Herding Bias}

Herding adalah suatu perilaku yang cenderung meniru perbuatan yang dilakukan oleh orang lain dari pada mengikuti keyakinannya ataupun informasi yang dimiliki (Hirshleifer dan Teoh, 2003). Perilaku herding merupakan bias perilaku yang paling umum terjadi dimana investor cenderung mengikuti keputusan investasi yang diambil oleh mayoritas. Alasan utama herding adalah tekanan atau pengaruh oleh rekan-rekan atau orang-orang sekitar.

\section{Pengaruh Cognitive Dissonance Bias Terhadap Pengambilan Keputusan Investasi Saham}

Cognitive dissonance bias (Bias disonansi kognitif $\backslash$ ) adalah konflik mental atau perasaan kegelisahan, stres atau ketidaknyamanan seseorang ketika dihadapkan dengan informasi baru yang menunjukkan bahwa keyakinan atau asumsi yang mereka pegang adalah salah, ketika investor bertindak melawan nilai-nilai mereka atau ketika mereka memegang dua atau lebih keyakinan atau nilai-nilai yang bertentangan (Valsova, 2016). Investor mencoba untuk merasionalisasi dan membenarkan tindakan dan keputusan mereka yang sebelumnya untuk menghindari disonansi kognitif karna menantang keputusan mereka di masa lalu. Keinginan untuk menghindari disonansi kognitif dapat menyebabkan pengulangan kesalahan dan keputusan yang buruk dalam investasi. Berdasarkan penelitian dan pernyataan terdahulu, maka penulis merumuskan hipotesis sebagai berikut :

$\mathbf{H}_{1}$ : Cognitive dissonance bias berpengaruh positif dan signifikan terhadap pengambilan keputusan investasi saham.

\section{Pengaruh Overconfidence Bias Terhadap Pengambilan Keputusan Investasi Saham}

Overconfidence merupakan bias yang melibatkan terlalu tingginya pengetahuan, keterampilan dan kemampuan seseorang untuk mengendalikan situasi dan meremehkan risiko yang ada (Valsova, 2016). Dalam hal investasi, terlalu percaya diri tampaknya memiliki aplikasi langsung yang cukup berbelit-belit yang melibatkan proyeksi masa depan. Terlalu percaya diri merupakan atribut yang mempengaruhi persepsi risiko individu karena investor yang terlalu percaya diri cenderung membuat keputusan mendadak yang menggambarkan perilaku pengambilan risiko mereka. Berdasarkan penelitian dan pernyataan terdahulu, maka penulis merumuskan hipotesis sebagai berikut: 
H2: Overconfidence bias berpengaruh positif dan signifikan terhadap pengambilan keputusan investasi saham.

\section{Pengaruh Herding Bias Terhadap Pengambilan Keputusan Investasi Saham}

Herding dalam konteks keuangan terjadi ketika seorang investor di pasar keuangan meniru perilaku investor lain atau kelompok investor yang lebih besar. Kasus klasik herding di bidang keuangan adalah kecenderungan investor individu untuk mengikuti keputusan investasi mayoritas bukan dengan hati-hati dan rasional menilai keputusan sendiri secara independen dari pendapat mayoritas (Valsova, 2016). Perilaku herding merupakan tindakan irasional dimana investor tidak mendasarkan keputusan investasinya pada informasi yang tersedia ataupun nilai fundamental perusahaan melainkan berdasarkan tindakan investor yang lainnya atau berdasarkan noise yang terjadi dalam pasar saham. Berdasarkan penelitian dan pernyataan terdahulu, maka penulis merumuskan hipotesis sebagai berikut :

H3: Herding bias berpengaruh positif dan signifikan terhadap pengambilan keputusan investasi saham

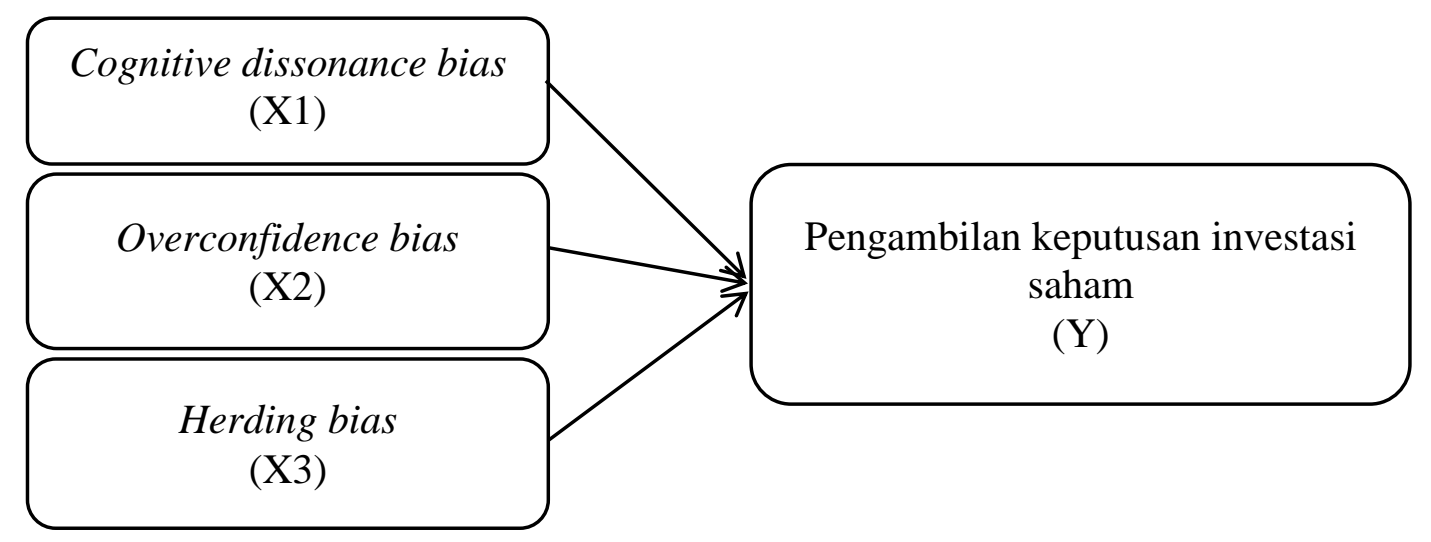

Gambar 1

Kerangka Konseptual

\section{METODE PENELITIAN}

\section{Jenis Penelitian dan Teknik Pengumpulan Data}

Jenis penelitian yang digunakan adalah kuantitatif yang kemudian diolah menggunakan uji asumsi klasik dengan menggunakan program SPSS. Sumber data yang digunakan dalam penelitian ini adalah data primer dengan metode survey. Alat analisis dalam penelitian ini menggunakan analisis regresi berganda. Teknik pengumpulan data menggunakan metode kuisioner yang langsung didistribusikan kepada responden. Alat ukur data dalam penelitian ini menggunakan skala likert.

\section{Populasi, Sampel Dan Teknik Pengambilan Sampel}

Populasi dalam penelitian ini adalah mahasiswa Fakultas Ekonomi Universitas Negeri Padang yang terdaftar dalam Galeri Investasi Bursa Efek Indonesia (GIBEI) FE UNP. Pada penelitian ini jumlah sampel sebesar 133 responden berdasarkan jumlah indikator sebanyak 19 buah dikali 7. Jadi melalui perhitungan tersebut didapatkan jumlah sampel sebesar 133 orang. Teknik pengambilan sampel yang digunakan dalam penelitian ini adalah simple random sampling. 


\section{Metode Analisis Data}

\section{a. Uji Asumsi Klasik}

\section{1) Uji Normalitas}

Uji normalitas dalam penelitian ini menggunakan Kolmogorov-Smirnov Z (1-Sample K-S). Jika nilai Asymp. Sig. < dari 0,05 maka berarti berdistribusi tidak normal, sebaliknya jika nilai Asymp. Sig. > dari 0,05 maka berarti berdistribusi normal.

\section{2) Uji Multikolinearitas}

Ada beberapa kriteria untuk mendeteksi multikolinearitas adalah sebagai berikut :

a) Dengan melihat nilai tolerance, apabila nilai tolerance lebih besar dari 0,10 maka tidak terjadi multikolinearitas dan sebaliknya apabila nilai tolerancenya lebih kecil dari 0,10 maka terjadi multikolinearitas.

b) Dengan melihat nilai VIF (Variance Inflation Factor), apabila nilai VIF lebih besar dari 10 maka terjadi multikolinearitas, sedangkan apabila lebih kecil dari 10 maka tidak terjadi multikolinearitas.

\section{3) Uji Heteroskedastisitas}

Uji heteroskedastisitas bertujuan untuk menguji apakah dalam model regresi terjadi ketidaksamaan variabel dari residual satu pengamatan ke pengamatan lain. Jika variance dari residual satu pengamatan ke pengamatan lain tetap makan disebut homoskedastisitas dan jika berbeda disebut heteroskedastisitas.

\section{b. Uji Hipotesis}

\section{1) Uji Regresi Linear Berganda}

Persamaan regresi berganda merupakan persamaan regresi dengan menggunakan dua atau lebih variabel independen. Bentuk umum persamaan regresi linear berganda adalah :

$$
\mathrm{Y}=\mathrm{a}+\mathrm{b} 1 \mathrm{X} 1+\mathrm{b} 2 \mathrm{X} 2+\mathrm{b} 3 \mathrm{X} 3=. . . .=\mathrm{e}
$$

\section{2) Uji Parsial (Uji T)}

Uji statistik $\mathrm{t}$ bertujuan untuk seberapa jauh pengaruh satu variabel penjelas secara individual dalam menerangkan variasi variabel terikat. Dengan Ho adalah parameter keberhasilan sama dengan nol, dan Ha parameter suatu variabel tidak sama dengan nol. Dasar pengambilan keputusan :

a) Jika probabilitas (signifikansi) $>0,05$ atau $t$ hitung $<\mathrm{t}$ tabel ,maka hipotesis tidak terbukti dan Ho diterima, Ha ditolak.

b) Jika probabilitas (signifikansi) $<0,05$ atau t hitung $>$ t tabel maka hipotesis terbukti dan Ho ditolak, Ha diterima.

\section{3) Uji Pengaruh Simultan (Uji F)}

Uji F dilakukan untuk menguji apakah semua variabel independen mempunyai pengaruh secara bersama-sama terhadap variabel dependen. Dengan tingkat signifikansi $5 \%$ maka kriteria pengujian sebagai berikut :

a) Apabila nilai signifikansi $\mathrm{f}<0,05$, maka $\mathrm{H} 0$ ditolak, bahwa terdapat pengaruh yang signifikan antara semua variabel independen terhadap variabel dependen. 
b) Apabila nilai signifikansi f $>0,05$, maka $\mathrm{H} 0$ diterima, bahwa tidak terdapat pengaruh yang signifikan antara semua variabel independen terhadap variabel dependen.

\section{4) Koefisien Dereterminasi $\left(\mathbf{R}^{2}\right)$}

Koefisien determinasi ( $\mathrm{R}$ square) pada intinya mengukur seberapa jauh kemampuan model dalam menerangkan variasi variabel dependen. Nilai koefisien determinasi adalah antara nol atau satu. Nilai R square yang kecil berarti kemampuan variabel independen dalam menjelaskan variasi variabel dependen sangat terbatas.

\section{HASIL DAN PEMBAHASAN}

a. Uji Asumsi Klasik

1) Uji Normalitas

Tabel . 1

Hasil Uji Normalitas

One-Sample Kolmogorov-Smirnov Test

\begin{tabular}{|c|c|c|}
\hline & & $\begin{array}{l}\text { Unstandardized } \\
\text { Residual }\end{array}$ \\
\hline $\mathrm{N}$ & & 133 \\
\hline \multirow[t]{2}{*}{ Normal Parameters ${ }^{a}$} & Mean & .0000000 \\
\hline & Std. Deviation & 2.45668907 \\
\hline \multirow[t]{3}{*}{ Most Extreme Differences } & Absolute & .044 \\
\hline & Positive & .042 \\
\hline & Negative & -.044 \\
\hline Kolmogorov-Smirnov Z & & .505 \\
\hline Asymp. Sig. (2-tailed) & & .961 \\
\hline
\end{tabular}

a. Test distribution is Normal.

Sumber : Pengolahan data statistis SPPS (2019)

Berdasarkan hasil tabel 4.13 uji normalitas diatas menunjukkan bahwa nilai Asymp. Sig sebesar 0,961 lebih besar dari nilai signifikansi 0,05. Dengan demikian dapat dikatakan bahwa data berdistribusi normal sehingga dapat memenuhi uji normalitas.

\section{2) Uji Multikolinearitas}

Tabel. 2 


\section{Hasil Uji Multikolinearitas \\ Coefficients $^{\mathrm{a}}$}

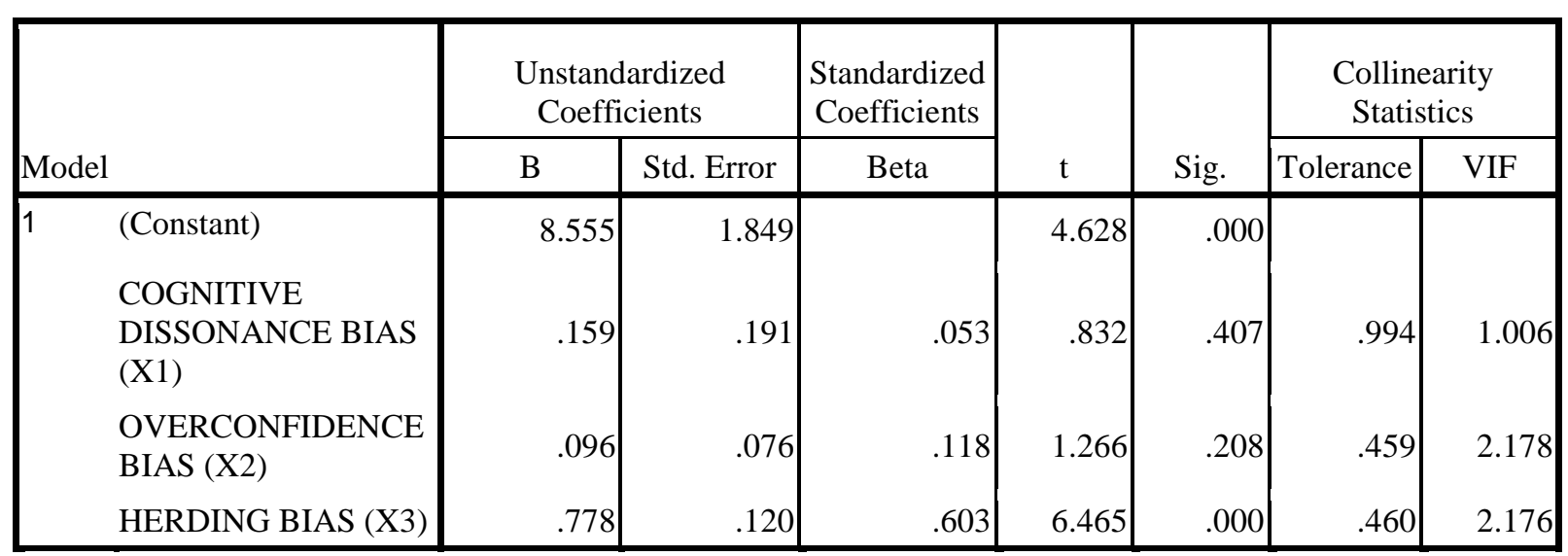

a. Dependent Variable: KEPUTUSAN INVESTASI $(\mathrm{Y})$

Sumber : Pengolahan data statistis SPSS (2019)

Berdasarkan tabel 4.14 hasil uji multikolinearitas diatas dapat dilihat bahwa variabel cognitive dissonance bias (x1) memiliki nilai VIF 1,006 < 10 dan nilai tolerance 0,994 > 0,10, overconfidence bias $(\mathrm{x} 2)$ dengan nilai VIF 2,178 $<10$ dan nilai tolerance 0,459>0,10 dan herding bias (x3) dengan nilai VIF 2,176 $<10$ dan nilai tolerance 0,460 $>0,10$. Dari hasil uji multikolinearitas dapat diambil kesimpulan bahwa untuk variabel cognitive dissonance bias, overconfidence bias dan herding bias tidak terdapat korelasi antar variabel independen, sehingga tidak terjadi gejala multikolinearitas.

\section{3) Uji Heteroskedastisitas}

Tabel 3

Hasil Uji Heteroskedastisitas

Coefficients $^{\mathrm{a}}$

\begin{tabular}{|c|c|c|c|c|c|c|}
\hline & & Unstandardize & Coefficients & $\begin{array}{l}\text { Standardized } \\
\text { Coefficients }\end{array}$ & & \\
\hline & & B & Std. Error & Beta & $\mathrm{t}$ & Sig. \\
\hline 1 & (Constant) & .595 & 1.122 & & .530 & .597 \\
\hline & $\begin{array}{l}\text { COGNITIVE } \\
\text { DISSONANCE BIAS } \\
\text { (X1) }\end{array}$ & .001 & .116 & .001 & .007 & .995 \\
\hline & $\begin{array}{l}\text { OVERCONFIDENCE } \\
\text { BIAS (X2) }\end{array}$ & .051 & .046 & .141 & 1.098 & 274 \\
\hline & HERDING BIAS (X3) & .015 & .073 & .027 & .211 & .833 \\
\hline
\end{tabular}

a. Dependent Variable: ABS_RES

Sumber : Pengolahan data statistis SPSS (2019)

Berdasarkan tabel 4.15 hasil uji heteroskedastisitas diatas menunjukkan nilai signifikansi variabel cognitive dissonance bias (x1) 0,995 > 0,05, nilai signifikansi variabel overconfidence 
bias (x2) 0,274 > 0,05, dan nilai signifikansi variabel herding bias (x3) 0,833>0,05. Sehingga dapat disimpulkan bahwa model regresi pada penelitian ini tidak terjadi gejala heteroskedastisitas.

\section{b. Uji Hipotesis}

1) Uji Regresi Linear Berganda

Tabel 4

Hasil Uji Regresi Berganda

Coefficients $^{\mathrm{a}}$

\begin{tabular}{|c|c|c|c|c|c|c|}
\hline \multirow{2}{*}{\multicolumn{2}{|c|}{ Model }} & \multicolumn{2}{|c|}{ Unstandardized Coefficients } & \multirow{2}{*}{$\begin{array}{c}\begin{array}{c}\text { Standardized } \\
\text { Coefficients }\end{array} \\
\text { Beta }\end{array}$} & \multirow[b]{2}{*}{$\mathrm{t}$} & \multirow[b]{2}{*}{ Sig. } \\
\hline & & B & Std. Error & & & \\
\hline 1 & (Constant) & 8.555 & 1.849 & & 4.628 & .000 \\
\hline & $\begin{array}{l}\text { COGNITIVE } \\
\text { DISSONANCE BIAS (X1) }\end{array}$ & .159 & .191 & .053 & .832 & .407 \\
\hline & $\begin{array}{l}\text { OVERCONFIDENCE } \\
\text { BIAS (X2) }\end{array}$ & .096 & .076 & .118 & 1.266 & 208 \\
\hline & HERDING BIAS (X3) & .778 & .120 & .603 & 6.465 & .000 \\
\hline
\end{tabular}

a. Dependent Variable: KEPUTUSAN INVESTASI (Y)

Sumber : Pengolahan data statistis SPSS (2019)

Berdasarkan tabel diatas dapat analisis model persamaan sebagai berikut :

$$
\begin{aligned}
& Y=a+b 1 X 1+b 2 X 2+b 3 X 3 \\
& Y=8,555+0,159 X 1+0,096 X 2+0,778 X 3
\end{aligned}
$$

Dimana :

$\mathrm{Y}=$ Keputusan investasi

$\mathrm{a}=$ Nilai Konstanta

$\mathrm{X} 1$ = Cognitive dissonance bias

$\mathrm{X} 2=$ Overconfidence bias

$\mathrm{X} 3=$ Herding bias

Dari persamaan diatas dapat disimpulkan sebagai berikut :

a) Nilai konstanta sebesar 8,555 menunjukkan bahwa jika variabel independen yaitu cognitive dissonance bias, overconfidence bias dan herding bias bernilai nol maka nilai keputusan investasi adalah sebesar nilai konstanta 8,555.

b) Koefisien variabel cognitive dissonance bias sebesar 0,159. Ini menunjukkan bahwa cognitive dissonance bias mempunyai pengaruh positif terhadap keputusan investasi. Koefisien tersebut dapat diartikan bahwa setiap peningkatan cognitive dissonance bias satusatuan, maka keputusan investasi meningkat sebesar 0,159 satuan dengan asumsi variabel lain dari model regresi bernilai tetap.

c) Koefisien variabel overconfidence bias sebesar 0,096. Ini menunjukkan bahwa overconfidence bias mempunyai pengaruh positif terhadap keputusan investasi. Hal ini berarti bahwa setiap peningkatan overconfidence bias satu-satuan, maka keputusan investasi meningkat sebesar 0,096 satuan dengan asumsi variabel lain dari regresi bernilai tetap. 
d) Koefisien variabel herding bias sebesar 0,778. Ini menunjukkan bahwa herding bias mempunyai pengaruh positif terhadap keputusan investasi. Hal ini berarti bahwa setiap peningkatan herding bias satu-satuan, maka keputusan investasi meningkat sebesar 0,778 satuan dengan asumsi variabel lain dari model regresi bernilai tetap.

\section{2) Uji Parsial (Uji T)}

a) Pengaruh variabel cognitive dissonance bias terhadap pengambilan keputusan investasi Hipotesis pertama adalah cognitive dissonance bias berpengaruh positif. Berdasarkan hasil tabel di atas, hipotesis pertama memiliki nilai t hitung 0,832 < 1,9785 dan nilai signifikansi $0,407>0,05$. Hal ini menunjukkan bahwa penelitian ini tidak dapat membuktikan cognitive dissonance bias berpengaruh signifikan terhadap keputusan investasi, dengan demikian hipotesis pertama $\left(\mathrm{H}_{1}\right)$ ditolak.

b) Pengaruh variabel overconfidence bias terhadap pengambilan keputusan investasi Hipotesis kedua adalah overconfidence bias berpengaruh positif. Berdasarkan hasil tabel di atas, hipotesis kedua memiliki nilai t hitung 1,266 < 1,9785 dan nilai signifikansi 0,208 $>$ 0,05. Hal ini menunjukkan bahwa penelitian ini tidak dapat membuktikan overconfidence bias berpengaruh signifikan terhadap keputusan investasi, dengan demikian hipotesis kedua $\left(\mathrm{H}_{2}\right)$ ditolak.

c) Pengaruh variabel herding bias terhadap pengambilan keputusan investasi

Hipotesis ketiga adalah herding bias berpengaruh positif. Berdasarkan hasil tabel di atas, hipotesis ketiga memiliki nilai t hitung 6,465 > 1,9785 dan nilai signifikansi $0,000<$ 0,005. Hal ini menunjukkan bahwa herding bias berpengaruh signifikan terhadap keputusan investasi, dengan demikian hipotesis ketiga $\left(\mathrm{H}_{3}\right)$ diterima.

\section{3) Uji Simultan (Uji F)}

\section{Tabel 5}

Hasil Uji F

ANOVA $^{\text {b }}$

\begin{tabular}{|ll|r|r|r|r|r|}
\hline Model & & Sum of Squares & df & Mean Square & F & Sig. \\
\hline 1 & Regression & 747.699 & 3 & 249.233 & 40.357 & $.000^{\mathrm{a}}$ \\
& Residual & 796.662 & 129 & 6.176 & & \\
Total & 1544.361 & 132 & & & \\
\hline
\end{tabular}

a. Predictors: (Constant), HERDING BIAS (X3), COGNITIVE DISSONANCE BIAS (X1), OVERCONFIDENCE BIAS (X2)

b. Dependent Variable: KEPUTUSAN INVESTASI (Y)

\section{Sumber : pengolahan data statistis SPSS (2019)}

Berdasarkan tabel 4.18 di atas menunjukkan hasil pengolahan statistik analisis regresi nilai $\mathrm{f}=40,357$ dan dengan nilai signifikansi $0,000<0,05$. Hal ini menunjukkan bahwa secara bersama-sama cognitive dissonance bias, overconfidence bias dan herding bias berpengaruh signifikan terhadap keputusan investasi. 


\begin{tabular}{|c|c|c|c|c|}
\hline \multicolumn{5}{|c|}{$\begin{array}{c}\text { Tabel } 6 \\
\text { Hasil Uji Koefisien Determinasi } \\
\text { Model Summary }\end{array}$} \\
\hline Model & $\mathrm{R}$ & R Square & $\begin{array}{l}\text { Adjusted R } \\
\text { Square }\end{array}$ & $\begin{array}{c}\text { Std. Error of the } \\
\text { Estimate }\end{array}$ \\
\hline 1 & $.696^{\mathrm{a}}$ & .484 & .472 & 2.48509 \\
\hline
\end{tabular}

Sumber : Pengolahan data statistis SPSS (2019)

Berdasarkan tabel 4.19 menunjukkan nilai koefisien adjusted $R$ square adalah 0472. Hal ini mengindikasikan bahwa kontribusi variabel independen terhadap variabel dependen sebesar 47,2 $\%$ sedangkan 52,8\% lainnya ditentukan oleh variabel lain yang tidak diketahui dan di model penelitian.

\section{PEMBAHASAN}

\section{Pengaruh Cognitive Dissonance Bias Terhadap Pengambilan Keputusan Investasi}

Berdasarkan hasil olahan statistik dalam penelitian ini dinyatakan bahwa hipotesis $1\left(\mathrm{H}_{1}\right)$ ditolak. Melalui pengujian regresi berganda, didapatkan nilai koefisien sebesar 0,159 , hal ini menunjukkan bahwa cognitive dissonance bias berpengaruh positif. Hipotesis pertama memiliki nilai t hitung sebesar 0,832<1,9785 dan nilai signifikansi $0,407>0,05$ yang artinya cognitive dissonance bias tidak berpengaruh signifikan terhadap pengambilan keputusan investasi. Jika cognitive dissonance bias mengalami peningkatan atau penurunan tidak akan mempengaruhi keputusan investasi dimana hasil ini tidak sesuai dengan prospect theory.

Hasil penelitian ini mendukung penelitian Pradhana (2018) yang membuktikan bahwa cognitive dissonance bias tidak berpengaruh terhadap pengambilan keputusan investasi karena responden dalam penelitian ini adalah mahasiswa. Mahasiswa memiliki kekompakan yang baik, dimana mereka akan saling bertukar informasi. Akibatnya, mereka tidak akan ragu jika mendapatkan informasi baru. Selain itu diprediksi bahwa cognitive dissonance bias tidak selalu menjadi salah satu faktor yang mempengaruhi seseorang dalam mengambil keputusan.

\section{Pengaruh Overconfidence Bias terhadap Pengambilan Keputusan Investasi}

Berdasarkan hasil olahan statistik dalam penelitian ini dinyatakan bahwa hipotesis $2\left(\mathrm{H}_{2}\right)$ ditolak. Melalui pengujian regresi berganda, didapatkan nilai koefisien sebesar 0,096. Nilai ini menunjukkan bahwa setiap peningkatan overconfidence bias satu-satuan maka keputusan investasi meningkat sebesar 0,096. Hipotesis kedua memiliki nilai t hitung sebesar 1,266 < 1,9785 dan nilai signifikansi $0,208<0,05$ yang artinya bahwa overconfidence bias tidak berpengaruh signifikan terhadap keputusan investasi.

Hasil penelitian ini mendukung hasil penelitian yang dilakukan oleh Paramita et al (2018) yang menyatakan overconfidence bias tidak berpengaruh pada perilaku investor. Kepercayaan diri yang berlebihan dapat menyebabkan investor yang berani melakukan transaksi saham yang berlebihan, sehingga berakibat pada return portofolio yang didapatkan akan lebih rendah. Terlalu percaya diri dapat menyebabkan investor menanggung risiko yang lebih besar. Responden dalam penelitian ini merupakan mahasiswa ekonomi yang sebenarnya memiliki pengetahuan yang cukup tentang saham, namun responden yang telah melakukan transaksi saham dengan frekuensi 
tinggi menghasilkan ketelitian analisis dan manfaat yang belum maksimal hanya sebagian yang mahir dalam transaksi saham. Oleh karena itu, responden memang memiliki pengetahuan yang cukup tentang saham namun belum memiliki kemampuan yang cukup mahir dalam praktik bertransaksi saham. Sehingga hal ini mempengaruhi tingkat kepercayaan diri yang berlebihan tentang transaksi saham. Dapat diartikan juga bahwa meskipun responden memiliki pengetahuan yang cukup tentang saham, tetapi mereka belum terampil dalam bertransaksi saham sebagai investor yang profesional. Masih kurangnya kemampuan responden dalam melakukan transaksi dan analisis saham sehingga responden masih menganggap saham adalah transaksi yang sangat berisiko.

\section{Pengaruh Herding Bias Terhadap Pengambilan Keputusan Investasi}

Berdasarkan hasil olahan statistik dalam penelitian ini dinyatakan bahwa hipotesis $3\left(\mathrm{H}_{3}\right)$ diterima. Melalui pengujian regresi berganda, didapatkan nilai koefisien sebesar 0,778. Nilai ini menunjukkan bahwa setiap peningkatan herding bias satu-satuan maka keputusan investasi akan meningkat sebesar 0,778. Hipotesis ketiga memiliki nilai t hitung sebesar 6,465 >1,9785 dan nilai signifikansi $0,000<0,05$ yang artinya bahwa herding bias berpengaruh signifikan terhadap keputusan investasi.

Hasil penelitian ini konsisten dengan penelitian Ramdani (2018) yang menyatakan bahwa variabel herding bias berpengaruh positif atau signifikan terhadap pengambilan keputusan investasi. Dari keputusan investor lain tersebut, investor lebih bereaksi cepat terhadap perubahan keputusan investor lain dalam berinvestsi. Selain itu juga investor lebih senang membeli saham jika saham tersebut diminati sejak awal diperdagangkan. Hasil penelitian ini sejalan dengan penelitian Qasim et al (2019) yang menunjukkan bahwa variabel herding bias memiliki dampak yang kuat pada keputusan investasi. Karna pasar saham pakistan yang tidak berkembang dengan baik dan efisien, sehingga informasi tidak tersedia untuk semua investor. Hal ini yang membuat investor dipengaruhi oleh herding bias untuk melindungi diri dari kerugian. Seorang investor akan menunjukkan perilaku herding ketika ia lebih bergantung pada informasi yang divalidasi oleh orang banyak, bukan pada penilaian sendiri karena dengan persepsi bahwa pilihan atau keputusan investasi yang diambil mayoritas tidak mungkin salah.

\section{KESIMPULAN, KETERBATASAN, DAN SARAN \\ Kesimpulan}

Berdasarkan hasil penelitian dan pembahasan yang telah dijelaskan sebelumnya, maka dapat ditarik kesimpulan sebagai berikut :

1. Dari temuan penelitian diketahui bahwa cognitive dissonance bias tidak berpengaruh signifikan terhadap keputusan investasi.

2. Dari temuan penelitian diketahui bahwa overconfidence bias tidak berpengaruh signifikan terhadap keputusan investasi.

3. Dari temuan penelitian diketahui bahwa herding bias berpengaruh positif signifikan terhadap keputusan investasi.

\section{KETERBATASAN}

Penelitian ini memiliki keterbatasan-keterbatasan yang dapat diperbaiki oleh peneliti selanjutnya. Keterbatasan dalam penelitian ini adalah sebagai berikut :

1. Penelitian ini hanya menggunakan 3 variabel yang belum menjelaskan pengaruh variabel dependen secara keseluruhan. 
2. Penelitian hanya menggunakan sampel pada mahasiswa Fakultas Ekonomi Universitas Negeri Padang dengan jumlah responden yang belum mencerminkan sikap investor secara keseluruhan yang dapat dipengaruhi oleh bias perilaku dalam mengambil keputusan investasi.

\section{Saran}

Berdasarkan hasil dan keterbatasan dalam penelitian ini, penulis dapat memberikan beberapa saran yang dapat dipertimbangkan untuk penelitian selanjutnya, antara lain sebagai berikut :

1. Bagi peneliti selanjutnya dapat menambah jumlah variabel penelitian di luar variabel yang telah peneliti gunakan sehingga mampu menjelaskan pengaruh bias terhadap pengambilan keputusan investasi.

2. Peneliti selanjutnya dapat menambah sampel responden yang digunakan menjadi lebih beragam dan hasil penelitian lebih menggambarkan keadaan yang sebenarnya terjadi pada investor saat mengambil keputusan investasi.

\section{DAFTAR PUSTAKA}

Aisyah, P., Erinos, N., \& Mulyani, E. (2019). Pengaruh Kualitas Informasi Akuntansi Dan Persepsi Kontrol Perilaku Terhadap Intensi Investor Dalam Pemilihan Saham. Jurnal Eksplorasi Akuntansi, 1(2), 769-780.

Aprillianto, B., Wulandari, N., \& Kurrohman, T. (2014). Perilaku investor saham individual dalam pengambilan keputusan investasi : studi hermeneutika-kritis. E-Journal Ekonomi Bisnis dan Akuntansi, 1 (1), 16-31.

Ar-rachman, A. R. 2018. Pengaruh Overconfidence Bias dan Bias Optimisme Terhadap Pengambilan Keputusan Investasi Pada Investor di Yogyakarta. Skripsi. Fakultas Ekonomi. Universitas Islam Indonesia.

Barber, B. M., \& Odean, T. (2000). Trading is hazardous to your wealth : The Common Stock Investment Performance Of Individul Investors. The Journal Of Finance, LV, 2.

Budiarto, A., \& Susanti. (2017). Pengaruh Financial Literacy, Overconfidence, Regret Aversion Bias dan Risk Tolerance terhadap Keputusan Investasi . Jurnal Ilmu Manajemen 05(02), $1-9$.

Bodie, Z., Kane, A., \& Marcus, A. (2016). Manajemen Portofolio dan Investasi. Edisi 9. Jakarta : Salemba Empat.

Danepo, M. 2018. Pengaruh Bias Perilaku Investor Terhadap Keputusan Investasi di Pasar Saham (studi pada Bursa Efek Indonesia). Tesis. Fakultas Ekonomi Dan Bisnis. Universitas Lampung.

Fityani, I. .2015. Analisis Investor Herding Behavior dengan Multinomial Logit Regression Pada BEI. Skripsi. Fakultas Ekonomi Dan Bisnis. Universitas Diponegoro.

Ghalandari, K., \& Ghahremanpour, J. (2013). The Effect of Market Variables and Herding Effect on Investment Decision as Factor Influencing Investment Peroformance in Iran. Journal of Basic and applied Scientific Research, 313-318.

Ghozali, I. (2005). Aplikasi Analisis Multivariate dengan Program SPSS. Semarang : Badan Penerbit Universitas Diponegoro.

Gozalie, S., \& Anastasia, N. (2015). Pengaruh Perilaku Heuristics dan Herding Terhadap Pengambilan Keputusan Investasi Properti Hunian. FINESTA, 3(1), 1-5. 
Gupta, Y., \& Ahmed, S. (2017). The Impact of Behavioral Biases on Investors Behavior in Indian Stock Market. International Journal of Management and Social Science Research Review, 1(37), 175-183.

Hirshleifer, D., \& Teoh, S. H. (2003). Limited attention, information disclosure, and finacial reporting. Journal of Accounting and Economics, 36, 337-386.

Humra, Y. (2014). Behavioral Finance : An Introduction to the Principles Governing Investor Behavior in Stock Markets. International Journal of Financial Management, 5(2), 23-30.

Jannah, W., \& Ady, S. U. (2017). Analisis Fundamental, Suku bunga dan Overconfidence Terhadap Pengambilan Keputusan Investasi Pada Investor di Surabaya. Jurnal Bisnis dan Manajemen, 1(2), 138-155.

Javed, H., Bagh, T., \& Razaaq, S. (2017). Herding effects, overconfidence, availibility bias and representativeness as behavioral determinant of preceived investment performance : an empirical evidence from pakistan stock exchange (PSX). Journal of Global Economics, 6(1), 1-13.

Kahneman, D., \& Tversky, A. (1979). Prospect Theory : An Analysis of Decision Under Risk. Journal of The Econometric Society, 47(2), 263-291.

Kengatharan, L. (2014). The Influence of Behavioral Factors in Making Investment Decisions and Performance : Study on Investors of Colombo Stock Exchange, Sri Lanka. Asian Journal of Finance \& Accounting, 6(1), 1-23.

Khan, A. R., Azeem, M., \& Sarwar, S. (2017). Impact of Overconfidence and Loss Aversion Biases on Investment Decision : Moderating Role of Risk Perception. Intenational Journal of Transformation in Accounting, Auditing \& Taxation, 23-34.

Khan, M. T. I., Tan, S. H., \& Chong, L. L. (2016). The Effect of Stated Preference For Firm Characteristics, Optimism and Overconfidence on Trading Activities. International Journal of Bank Marketi, 34(37).

Kumar, S., \& Goyal, N. (2015). Behavioral biases in investment decision making - a systematic literature review. Qualitative Research in Financial Markets, 7(1), 88-108.

Lika-liku IHSG selama setahun bak Roller Coaster. Diakses 20 Mei 2019, dari http://www.alinea.id

Paramita, R. S., Isbanah, Y., \& Purwohandoko. (2018). Bias Kognitif dan Kepribadian Individu : Studi Perilaku Investor Muda di Surabaya. Jurnal Riset Manajemen Sains Indonesia, 9(2), 214-235.

Pradhana, R. W. (2018). Pengaruh Finacial Literacy, Cognitive Bias dan Emotional Bias terhadap Keputusan Investasi . Jurnal Ilmu Manajemen, 6(3), 108-117.

Pradikasari, E., \& Isbanah, Y. (2018). Pengaruh Financial Literacy, Illusion of Control, Overconfidence, Risk Tolerance, Dan Risk Perception Terhadap Keputusan Investasi Pada Mahasiswa di Kota Surabaya. Jurnal Ilmu Manajemen, 6(4), 424-434.

Puspaningtyas, Z. (2010). Relevansi nilai informasi akuntansi dan manfaatnya bagi investor. Jurnal Ekonomi dan Keuangan.

Puspitaningtyas, Z. (2007). Pemanfaatan informasi akuntansi bagi investor dalam proses pengambilan keputusan investasi. Jurnal $\mathrm{NeO}$-Bis, 1(2).

Qasim, M., Hussain, R. Y., Mehboob, I., \& Arshad, M. (2019). Impact of herding behavior and overconfidence bias on investors decision making in pakistan. Accounting, 5, 81-90.

Ramdani, F. N. (2018). Analisis Pegaruh Representiveness Bias dan Herding Behavior Dalam Pengambilan Keputusan Investasi (Studi pada mahasiswa di Yogyakarta). Skripsi. Fakulas Ekonomi. Universitas Islam Indonesia. 
Ricciardi, V., \& Simon, H. K. (2000). What is Behavioral Finance . Business, Education and Technology Journal Fall, 1-9.

Setiawan, Y. C., Atahau, A. D., \& Robiyanto. (2018). Cognitive Dissonance Bias, Overconfidence Bias dan Herding Bias dalam Pengambilan Keputusan Investasi Saham. Accounting and Financial Review, 1 (1), 17-25.

Seto, A. A. (2017). Behavioral Biases pada Individual Investor di Kota Palembang. Jurnal Ilmiah Ekonomi Global Masa Kini, 8(01), 6-11.

Statman, M. (2014). Behavioral finance : Finance with normal people. Borsa istanbul Review, 19.

Suartana, I Wayan. (2010). Akuntansi Keperilakuan : Teori dan Implementasi. Yogyakarta : Andi.

Subash, R. (2012). Role of Behavioral Finance in Portfolio Investment (Decisions : Evidence from India). Tesis. Faculty of Social Sciences. Charles University in Prague.

Sugiyono. (2012). Metode Penelitian Administrasi. Bandung : Alfabeta.

Sumtoro, A., \& Anastasia, N. (2015). Perilaku Keuangan dalam Pengambilan Keputusan Berinvestasi Properti Residensial di Surabaya. FINESTA,. 3(1), 41-45.

Tandelilin, E. (2010). Portofolio dan Investasi : Teori dan Aplikasi. Yogyakarta : Kanisius.

Umairoh, P. (2012). Cognitive Bias dan Emotional Bias dalam Pengambilan Keputusan Investasi Portofolio. Skripsi. Fakultas Ekonomi Dan Bisnis. Universitas Kristen Satya Wacana.

Valsova, D. 2016. Behavioral Finance and Its Practical Implications for Investment Profesionals. Tesis. State University of New York.

Waweru, N. M., Mwangi, G. G., \& Parkinson, J. M. (2014). Behavioural factors influencing investment decisions in the Kenyan property market. Afro-Asian J. Finance and Accounting, 4(1), 24-49. 